\title{
WINE DRINKS IN BULGARIA: KEY TRENDS AND FUTURE PERSPECTIVES
}

\author{
T. Dimitrova* \\ Department of Marketing and International Economic Relations, Faculty of Economic and Social \\ Sciences, Plovdiv University "Paisii Hilendarski”, Plovdiv, Bulgaria
}

\begin{abstract}
This paper reviews the market for wine drinks in Bulgaria. It charts the key trends, as it utilizes latest data on production, volume and value by category of wine drinks, by transacted deals, import and export, profitability, liquidity, indebtedness. The paper discusses the impact of several microeconomic and macroeconomic factors of this industry. For the purposes of this paper, the market has been defined to include: sparkling wines, still (table) wines, special wines.
\end{abstract}

Key words: alcohol drinks market, wine drinks.

\section{Main trends in the development of wine market in Bulgaria in the period 2011 - 2015.}

Bulgaria has long traditions in wine growing and wine production. The country enjoys favourable natural and climatic conditions for the development of viticulture, good potential of local and introduced grape varieties and specialized areas and regions for healthy growth and development of vineyards. Wine industry is an important sector for the Bulgarian economy. It is competitive, hightech and export-oriented. International markets are familiar with Bulgarian wine and there is a growing potential for developing and advancing its market position overseas.

\subsection{Macroeconomic framework Gross domestic product}

Since 2013 onwards, the economic activity in Bulgaria has been gradually accelerating. Although the growth of the gross domestic product (GDP) is still significantly lower than the rates before 2008, it reached 3\% in 2015 supported mainly by the positive tendencies in the external sector. Data of the Bulgarian Ministry of Finance (1) show that in 2016 GDP marked a stable growth by $3.4 \%$ of real

\footnotetext{
*Correspondence to: Teofana Dimitrova, Department of Marketing and International Economic Relations, Faculty of Economic and Social Sciences, Plovdiv University "Paisii Hilendarski”, Plovdiv 4000, Bulgaria 24 Tsar Asen St., GSM: +359885715 390, E-mail:teo_dimitr@abv.bg
}

economic gains. It is a balanced growth substantiated by both internal demand $(1.6 \%)$ and by net export (1.8\%).

\section{Gross value added}

The gross value added (GVA) produced by the national economy industry sectors in 2015 was reported at 39134 million EUR at current basic prices. In real terms it increased by $3 \%$ in comparison with the preceding year. The added value of agricultural sector entities in 2015 amounted to 1873 million EUR at current basic prices, shrinking by $6.8 \%$ per annum in real terms. The share of agriculture in the total GVA drops under 5\% for the first time since there is GVA statistics in the country.

Gross value added in 2016 was reported at 79.9 billion BGN. The estimated value is $2.9 \%$ higher than in 2015. The most significant contribution to the growth is made by the service sector, accounting for $67.6 \%$ of GVA. The industrial sector accounts for $28.0 \%$ of gross value added and the agricultural sector $4.4 \%$.

\section{Employment and unemployment}

The positive trend of onward developments in the labour market from recent years has remained in place. The unemployment level decreased substantially in 2015 to $9.2 \%$ (2). As this ongoing decrease continued, it reached $6.7 \%$ in the forth quarter which is the lowest estimate since the middle of 2009. However, the decline in unemployment had no 
significant impact on employment largely due to the reduced labour supply. The employment coefficient in 2016 indicated decline for all age groups (except for people over 65) as compared to the previous year.

\section{Foreign direct investment}

Despite positive economic developments in the country, the growth of investment activity in Bulgaria gradually slowed down and resulted in decline in foreign direct investment over the last year. According to the reports of BNB (3) the amount of FDI in Bulgaria for the entire 2016 was 682.8 million EUR which is approximately 1 billion EUR less than in 2015 . If a longer comparison period is covered, the FDI flow in 2016 remains more than two times smaller than the average annual rate for 2010 2015.

\section{Inflation}

The average annual inflation for 2015 was $0.1 \%$. Consumer price change (according to the harmonised index of consumer prices) has been negative for the entire 2016 with the annual deflation rate slowing down to $-0.5 \%$ in December. The average annual inflation remains negative $(-1.3 \%)$.

\section{Commodity exchange}

In 2015, Bulgaria's export hit a record high reaching nearly 29 billion Euro and 1 billion EUR growth as against 2014. The total export of goods to the EU countries increased by $7.9 \%$ and the registered growth to third parties was insignificant $-0.6 \%$. Foreign trade data show that export exceeded the value of imports. In 2016, Bulgaria's exports figure was increased by 325 million EUR or $5.7 \%$ in comparison to the preceding year. The value of imported goods increased by 177 million EUR or $2.7 \%$.

\subsection{Production}

Wine production in Bulgaria in the period $2011-2013$ is characterized by positive trends on annual growth reaching its highest level in 2013 (165 898000 litres). The total growth rate for 2013/2014 reached negative value of $40.9 \%$. In comparison, the figure for 20122013 is $0.2 \%$. However, this negative trend is considered not to be widening. 2015 registered upward move of production in comparison to the preceding year (by $40.3 \%$ or 39.5 liters). As shown in Table 1, in 2015 production increased in all product classes in comparison to 2014. The best performing segment is the one of high quality red wines and rosè registering growth rate by $86.5 \%$ for $2014 / 2015$ or 1.5 million liters, followed by sparkling wines $(48.2 \%)$, table wines $(39.8 \%)$, vermouths and other aromatised wines (32.7), and high quality white wines (2.8\%).

The biggest share in the product mix of wine production enterprises in 2015 have the table wines (non $-\mathrm{PDO}^{1}$ still wines) $-96 \%$. The changes as against 2014 are:

- Increase in the share of PDO still wines by $0.4 \%$ and of sparkling wines by $0.02 \%$.

- Decrease in the share of non-PDO still wines - by $0.4 \%$, of vermouths and other aromatised wines - by $0.1 \%$.

Table 1. Production of grape wine $(2011-2015)$, in '000 liters

\begin{tabular}{|c|c|c|c|c|c|}
\hline $\begin{array}{l}\text { Year } \\
\text { Product line }\end{array}$ & 2011 & 2012 & 2013 & 2014 & 2015 \\
\hline Sparkling wines & 1298 & 705 & 739 & 307 & 455 \\
\hline Still wines & 121024 & 140308 & 161361 & 96658 & 135674 \\
\hline PDO still wines & 3458 & 3579 & 3104 & 2395 & 3928 \\
\hline Red wines and rosè & 2982 & 3021 & 2582 & 1751 & 3266 \\
\hline White wines & & & & & \\
\hline Non PDO still wines & 117567 & 136729 & 158257 & 94263 & 131746 \\
\hline Special wines & 990 & 2147 & 2314 & 1135 & 1506 \\
\hline $\begin{array}{l}\text { Liqueur wines } \\
\text { Vermouth and others aromatised wines }\end{array}$ & $\begin{array}{l}.2 \\
990\end{array}$ & $\begin{array}{l}17 \\
2130\end{array}$ & $\ddot{2} 314$ & $\ddot{1} 135$ & $\ddot{1} 506$ \\
\hline Grape must & 2175 & 335 & 1484 & .. & .. \\
\hline Total & 125487 & 143495 & 165898 & 98101 & 137635 \\
\hline
\end{tabular}

Source: SFB Capital Market

\footnotetext{
${ }^{1}$ Protected Designation of Origin, wines produced in EU

${ }^{2}$.. - Confidential data
} 


\subsection{Wine sales}

From the analysis of the data shown in Table 2 it can be concluded that there is a positive trend of annual increase in the physical volume sales in the period $2011-2013$. Wine consumption reached its highest level in 2013 when wine sales amounted to 125.4 liters. In comparison to 2014, the volume sales of producers in 2015 increased (by $5.1 \%$ or by 4.7 million liters), and the sales in value registered substantial change (decrease by only 11000 EUR, or $0.01 \%$ ).

Table 2. Grape wine sales $(2011-2015)$

\begin{tabular}{|c|c|c|c|c|c|c|c|c|c|c|}
\hline \multirow{2}{*}{$\begin{array}{l}\text { Year } \\
\text { Product } \\
\text { lines }\end{array}$} & \multicolumn{2}{|l|}{2011} & \multicolumn{2}{|l|}{2012} & \multicolumn{2}{|l|}{2013} & \multicolumn{2}{|l|}{2014} & \multicolumn{2}{|l|}{2015} \\
\hline & $\begin{array}{l}000 \\
\text { liters }\end{array}$ & $\begin{array}{l}000 \\
\text { EUR }\end{array}$ & \begin{tabular}{|l|}
000 \\
liters
\end{tabular} & $\begin{array}{l}\text { '000 } \\
\text { EUR }\end{array}$ & $\begin{array}{l}\mathbf{0 0 0} \\
\text { liters }\end{array}$ & $\begin{array}{l}\text { '000 } \\
\text { EUR }\end{array}$ & $\begin{array}{l}\mathbf{0 0 0} \\
\text { liters }\end{array}$ & $\begin{array}{l}\text { '000 } \\
\text { EUR }\end{array}$ & $\begin{array}{l}\mathbf{0 0 0} \\
\text { liters }\end{array}$ & $\begin{array}{l}000 \\
\text { EUR }\end{array}$ \\
\hline $\begin{array}{l}\text { Sparklin } \\
\text { g wines }\end{array}$ & \begin{tabular}{|l|}
748 \\
\end{tabular} & 1060 & 745 & 1033 & 639 & 932 & 280 & 475 & 399 & 601 \\
\hline $\begin{array}{l}\text { Still } \\
\text { wines }\end{array}$ & $\begin{array}{l}10902 \\
2\end{array}$ & $\begin{array}{l}10663 \\
0\end{array}$ & $\begin{array}{l}10766 \\
2\end{array}$ & $\begin{array}{l}10881 \\
2\end{array}$ & $\begin{array}{l}12252 \\
9\end{array}$ & $\begin{array}{l}11960 \\
4\end{array}$ & 92616 & $\begin{array}{l}10481 \\
2\end{array}$ & 95691 & $\begin{array}{l}10358 \\
6\end{array}$ \\
\hline $\begin{array}{l}\text { PDO still } \\
\text { wines }\end{array}$ & 1893 & 6420 & 1750 & 6857 & 1763 & 7548 & 2040 & 8468 & 2588 & 11810 \\
\hline $\begin{array}{l}\text { Red } \\
\text { wines and } \\
\text { rosè }\end{array}$ & 1549 & 5056 & 1215 & 5039 & 1286 & 5455 & 1479 & 6301 & 2001 & 9496 \\
\hline $\begin{array}{l}\text { White } \\
\text { wines }\end{array}$ & 344 & 1364 & 536 & 1819 & 477 & 2092 & 561 & 2167 & 586 & 2314 \\
\hline $\begin{array}{l}\text { Non- } \\
\text { PDO still } \\
\text { wines }\end{array}$ & $\begin{array}{l}10712 \\
9\end{array}$ & $\begin{array}{l}10021 \\
0\end{array}$ & $\begin{array}{l}10591 \\
2\end{array}$ & $\begin{array}{l}10195 \\
5\end{array}$ & $\begin{array}{l}12076 \\
5\end{array}$ & $\begin{array}{l}11205 \\
6\end{array}$ & 90576 & 96344 & 93104 & 91777 \\
\hline $\begin{array}{l}\text { Special } \\
\text { wines }\end{array}$ & \begin{tabular}{|l|}
977 \\
\end{tabular} & .. & \begin{tabular}{|l|}
2284 \\
\end{tabular} & 2279 & 2276 & 2697 & .. & .. & 1542 & 1089 \\
\hline $\begin{array}{l}\text { Liqueur } \\
\text { wines }\end{array}$ &.. & .. & 18 & 53 &.. & .. & .. &.. & 246 &.. \\
\hline $\begin{array}{l}\text { Vermout } \\
\text { h and } \\
\text { other } \\
\text { aromotise } \\
\text { d wines }\end{array}$ & 977 & .. & 2266 & 2226 & 2276 & 2697 & .. & .. & 1296 & 1089 \\
\hline $\begin{array}{l}\text { Grape } \\
\text { must }\end{array}$ & .. & . & 476 & 225 & .. & .• & .. & .• & .• & .• \\
\hline $\begin{array}{l}\text { Total } \\
\text { sales }\end{array}$ & $\begin{array}{l}11074 \\
7\end{array}$ & \begin{tabular}{|l|}
10769 \\
0
\end{tabular} & $\begin{array}{l}11116 \\
7\end{array}$ & $\begin{array}{l}11235 \\
0\end{array}$ & $\begin{array}{l}12544 \\
4\end{array}$ & $\begin{array}{l}12323 \\
3\end{array}$ & $\begin{array}{l}9289 \\
6\end{array}$ & $\begin{array}{l}10528 \\
7\end{array}$ & $\begin{array}{l}9763 \\
2\end{array}$ & $\begin{array}{l}10527 \\
6\end{array}$ \\
\hline
\end{tabular}

Source: SFB Capital Market

As evident by the figures, the best performing segment in the period $2011-2015$ is the one of table wines (non-PDO still wines) which has clearly reaffirmed it as the fastest growing product line in the period.

The trends in the average price of sold quantities are as follows (4):

- increase by $45 \%$ for PDO still red wines and rosè - from 3.26 EUR per liter in 2011 to 4.74 EUR per liter in 2015;

- the price for PDO still white wines is wavering - decrease by $0.3 \%$ as compared to 2011 , but in comparison to 2014 it is increased by $2.2 \%$;

- increase by $5.4 \%$ for non-PDO still wines as compared to 2011 and decrease by $7.3 \%$ as compared to 2014;

- the price for sparkling wines was highest in 2014 and in 2015 the decrease against 2014 is by $11.2 \%$. In comparison to 2011 , the price for sparkling wines increased by $6.3 \%$ in 2015 .

\subsection{Commodities exchange}

Bulgaria's commodities exchange with wines from fresh grapes in the period $2011-2015$ follows a wavering trend of growth and decline (Table 3). In 2012 the commodity exchange registered highest values and in 2015 - lowest values. The total growth rate in 2014/2015 was by $-0.9 \%$ or 525100 EUR. 
DIMITROVA T.

Table 3. Commodities exchange of wines from fresh grapes and foreign trade balance (2011-2015)

\begin{tabular}{|c|c|c|c|c|c|c|c|c|c|c|}
\hline \multirow{2}{*}{$\begin{array}{l}\text { Year } \\
\text { Index }\end{array}$} & \multicolumn{2}{|l|}{2011} & \multicolumn{2}{|l|}{2012} & \multicolumn{2}{|l|}{2013} & \multicolumn{2}{|l|}{2014} & \multicolumn{2}{|l|}{2015} \\
\hline & $\begin{array}{l}000 \\
\text { liters }\end{array}$ & $\begin{array}{l}\text { '000 } \\
\text { EUR }\end{array}$ & $\begin{array}{l}000 \\
\text { liters }\end{array}$ & $\begin{array}{l}\text { '000 } \\
\text { EUR }\end{array}$ & \begin{tabular}{|l|} 
'000 \\
liters
\end{tabular} & $\begin{array}{l}\text { '000 } \\
\text { EUR }\end{array}$ & $\begin{array}{l}000 \\
\text { liters }\end{array}$ & $\begin{array}{l}\text { '000 } \\
\text { EUR }\end{array}$ & \begin{tabular}{|l|}
$\mathbf{0 0 0}$ \\
liters
\end{tabular} & $\begin{array}{l}\text { '000 } \\
\text { EUR }\end{array}$ \\
\hline $\begin{array}{l}\text { Commodities } \\
\text { exchange }\end{array}$ & - & $\begin{array}{l}63 \\
684\end{array}$ & - & $\begin{array}{l}65 \\
244\end{array}$ & - & $\begin{array}{l}63 \\
558\end{array}$ & - & $\begin{array}{l}57 \\
187\end{array}$ & - & $\begin{array}{l}56 \\
662\end{array}$ \\
\hline Export & $\begin{array}{l}60 \\
381\end{array}$ & $\begin{array}{l}51 \\
828\end{array}$ & $\begin{array}{l}60 \\
287\end{array}$ & $\begin{array}{l}51 \\
606\end{array}$ & \begin{tabular}{|l|}
53 \\
948
\end{tabular} & $\begin{array}{l}49 \\
200\end{array}$ & $\begin{array}{l}45 \\
556\end{array}$ & $\begin{array}{l}43 \\
359\end{array}$ & $\begin{array}{l}39 \\
859\end{array}$ & $\begin{array}{l}37 \\
279\end{array}$ \\
\hline Import & 5961 & $\begin{array}{l}11 \\
856\end{array}$ & 5853 & $\begin{array}{l}13 \\
637\end{array}$ & 5499 & $\begin{array}{l}14 \\
358\end{array}$ & 3771 & $\begin{array}{l}13 \\
828\end{array}$ & 7409 & $\begin{array}{l}19 \\
383\end{array}$ \\
\hline $\begin{array}{l}\text { Foreign } \\
\text { trade } \\
\text { balance }\end{array}$ & - & $\begin{array}{l}39 \\
973\end{array}$ & - & $\begin{array}{l}37 \\
969\end{array}$ & - & $\begin{array}{l}34 \\
841\end{array}$ & - & $\begin{array}{l}29 \\
531\end{array}$ & - & $\begin{array}{l}17 \\
896\end{array}$ \\
\hline
\end{tabular}

Source: National Statistical Institute

The foreign trade balance for the entire period is positive with a decreasing trend. For 2015 it declined by $39.4 \%$ or 11.6 million EUR in comparison to the previous year.

\section{Import}

In the period 2011 - 2014, the import volume of wine decreased (except in 2012) but its value increased (except in 2014). In 2015, 9.2 million liters were imported amounting to 19.4 million EUR. As compared to 2014, the quantities registered growth by $75.2 \%$ (or 3.9 million liters) and the value increased by $40.2 \%$ (or 5.5 million EUR).

In 2014, still red wines and rosè had the biggest share $(42.5 \%)$ in the distribution of imported quantities of wine in terms of product lines, followed by still white wines (38.2\%).
Still white wines had biggest share in imported value (34\%) and still red wines and rosè (28.9).

\section{Export}

As evident by the data shown in Table 3, there is an ongoing decline in wine export in the period 2011 - 2015. In 2015 Bulgaria exported 39.9 million liters at 37.3 million EUR. The growth of export in 2014/2015 was a negative figure (both in volume $-12.5 \%$ and in value $14 \%)$. Still red wines and rosè had biggest share in the distribution of exported products lines in the last year.

\subsection{Financial indicators of the enterprises from "Production of grapes wine"}

As evident by Table 4, the liquidity of wine producers in 2015 was lower than in the preceding year.

Table 4. Financial indicators of the enterprises from „Production of wine from grapes “ (2011-2015)

\begin{tabular}{|l|l|l|l|l|l|}
\hline Indicator/Year & 2011 & 2012 & 2013 & 2014 & 2015 \\
\hline General liquidity ratio & 1.48 & 1.51 & 1.19 & 1.40 & 1.38 \\
\hline Fast liquidity ratio & 0.65 & 0.67 & 0.48 & 0.59 & 0.63 \\
\hline Return on sales & -0.07 & -0.07 & -0.03 & -0.07 & -0.14 \\
\hline Return on equity ratio & -0.06 & -0.07 & -0.03 & -0.07 & -0.14 \\
\hline Debt ratio & 1.737 & 2.149 & 2.548 & 2.359 & 2.170 \\
\hline Sales revenue ('000 BGN) & 250561 & 250293 & 243790 & 237423 & 248277 \\
\hline Financial result ('000 BGN) & -17778 & -16982 & -8251 & -17366 & -35954 \\
\hline
\end{tabular}

Source: Independent calculations and SFB Capital Market

The total liquidity ratio in 2015 was highest in (4):

- Bulgarian wine and spirits AD - Sofia;

- Papas Vineks AD - Yambol;

- Vinprom Montana AD - Montana;

- Slaveykovo Cellar EAD - Harmanli;

- Koveks 2 EOOD - Panagyurishte.

The profitability of the sector enterprises is negative for the entire period which is a logical consequence of the financial result.
Profits exceeding 1 million BGN for 2015 registered the following companies (4):

- Villa Yambol EAD - Yambol: 3673 000 BGN;

- $\quad$ New Industrial Company AD - Sofia: 2 289000 BGN.

Loss exceeding 1 million BGN registered the following companies:

- Angels Estate AD - Stara Zagora: -1 047 000 BGN; 
- LVK Vinprom AD - Targovisthe: -1 258 000 BGN;

- Ivena Commerce - Valentin Shotev Sole Propritorship - Sofia: -1 327000 BGN;

- Domain Menada EOOD - Sofia: -1 399000 BGN;

- Vinprom Haskovo EAD - Sofia: -1 434000 BGN;

- Karabunar Cellar OOD - Sofia: -1 456000 BGN;

- Bulgarian Wine and Spirits AD - Sofia: -1 500000 BGN;

- Noviko Nord EOOD - Chipran: -1 769000 BGN;

- Telish AD - Sofia: -24678 000 BGN.

Companies debt in 2015 was lower than in the previous year.

Lowest debt ratio over the last year registered the following enterprises (4):

- Koveks 2 EOOD - Panagyurishte;

- Dionisiy AD - Nikopol;

- Midalidare Vineyards EOOD - Mogilovo;

- Balar AD - Skalitsa;

- Wine Mansion Santa Sara AD - Goritsa.

\section{Perspectives on the development of wine market in Bulgaria}

Wine producers in Bulgaria have a number of technical, operational, business and innovation resources at hand. Part of their perspectives for development can be sought in the maximum absorption of the EU funds and more active participation in the national programmes for supporting the business.

The National Vine and Wine Programme 2014-2018 aimes to provide assistance to Bulgarian wine makers in the form of financing for renewal and restructuring of vineyards, improving the vineyard management methods and techniques, improving market positions in the non-EU countries. It kept operating in 2015. The programme includes four measures "Restructuring and conversion of vineyards"; "Green harvesting", "Promotion on third countries markets", "Company investments". After a wide-ranging discussion between representatives of the administration and the wine sector, the Permanent working group for operational problem solving in Wine department made a decision to exclude the measure "Company investments" from the scope of the Programme, and allocate the funds amounting to 66497200 BGN (16 624300 per annum) to the measure "Restructuring and conversion of vineyards" (5).
"Restructuring and conversion of vineyards" is the measure with the most successful implementation. Its significance for the sector is key. It sustains considerable interest on behalf of the producers. Eligible for receiving financial support are activities related with: change in plant variety; vineyard restructuring; improving the vineyard management methods and techniques. The maximum amount of financial aid is up to $75 \%$ of the amount of the actual costs for the implementation of each specific activity.

Measure "Promotion on third countries markets" aims to improve the competitiveness, to strengthen the prestige and to enhance the demand (outside the EU) of $\mathrm{PDO}$ and $\mathrm{PGI}^{3}$ Bulgarian wines. The financing with European funds is up to $50 \%$ and the national co-financing - up to $30 \%$ of the total amount of the implemented activities.

Measure "Green harvesting" is a safety tool applicable in crisis situations. It helps to recover the balance between demand and supply on the wine market in the European Union. In 2015, this measure was not implemented in Bulgaria and its annual budget amounting to $1173480 \mathrm{BGN}$ was transferred to the budget of "Restructuring and conversion of vineyards". According to data of the Ministry of Agriculture and Food in the period from the beginning of the financial 2016 (16.10.2015) to 14.06.2016, there were 198 applications submitted for financial aid by the measure "Restructuring and conversion of vineyards". 127 agreements have been signed amounting to total financial aid of 48565960 BGN. The amount of payments made is 7597 525 BGN (5).

\section{REFERENCES}

1. Bulgarian Ministry of Finance, Spring Macroeconomic Forecast - 2017.

2. Bulgarian Academy of Science, Economic development and policy in Bulgaria: evaluations and expectations, Goreks Pres, S., 2016.

3. Bulgarian Development Bank, Economic and financial observer Q4 2016, <www.bbr.bg>, (06.2017).

4. SFB Capital Market, Wine report 2015.

5. Ministry of Agriculture, Food and Forestry, Annual report on the situation and development of agriculture -2016 .

\footnotetext{
${ }^{3}$ Protected Geographical Indication wines
} 